\title{
Penggunaan Media Pembelajaran Audio Visual dalam Mata Pelajaran PKn
}

\author{
Faizah
}

SD Negeri 101768 Tembung, Percut Sei Tuan, Deli Serdang, Indonesia

Diterima Pebruari 2017; Disetujui April 2017; Dipublikasikan Juni 2017

\begin{abstract}
Abstrak
Untuk meningkatkan hasil belajar siswa pada mata pelajaran PKn tentang akibat tidak memelihara lingkungan, maka peneliti menggunakan media pembelajaran Audio Visual. Penelitian ini menggunakan metode penelitian tindakan kelas dengan dua siklus. Tiap siklus terdiri atas tahap perencanaan, tindakan, observasi, dan refleksi. Pengambilan data dilakukan dengan tes. Alat pengambilan data yang digunakan adalah angket, observasi, dan dokumentasi. Teknik analisis data yang digunakan yaitu teknik kuantitatif dan kualitatif. Hasil penelitian menunjukkan bahwa, data hasil belajar yang diperoleh peserta didik pada siklus I ratarata 83 (baik) dan mengalami kenaikan pada siklus II rata-rata 92,23 (sangat baik). Dan untuk motivasi siswa terhadap media pembelajaran audio visual pada siklus I sebesar 80\% (baik) sedangkan pada siklus II sebesar 90,6\% (baik). Secara keseluruhan nilai yang diperoleh untuk setiap aspek pernyataan dalam angket mengalami peningkatan. Berdasarkan hasil penelitian tersebut, terbukti bahwa penerapan penggunaan media pembelajaran audio visual terhadap pembelajaran PKn dapat meningkatkan hasil belajar siswa. Oleh sebab itu, peneliti menyarankan agar guru kelas menggunakan media pembelajaran audio visual dalam mengajar di kelas.
\end{abstract}

Kata Kunci : Hasil Belajar, Media Audio Visual, Pembelajaran PKn

\begin{abstract}
To improve student learning outcomes on Civics subjects about the consequences of not maintaining the environment, the researchers used Audio Visual learning media. This research uses classroom action research method with two cycles. Each cycle consists of planning, action, observation, and reflection. Data collection is done by test. The data collection tools used are questionnaires, observation, and documentation. Data analysis techniques used are quantitative and qualitative techniques. The results showed that, learning result data obtained by learners in cycle I mean 83 (good) and experience increase in cycle II average 92,23 (very good). And for student motivation on audio visual learning media in cycle I is $80 \%$ (good) while in cycle II equal to 90,6\% (good). Overall the value obtained for each aspect of the statement in the questionnaire has increased. Based on the results of these studies, it is evident that the application of the use of audio visual learning media on learning Civics can improve student learning outcomes. Therefore, the researcher recommends that classroom teachers use audio-visual learning media in classroom teaching.
\end{abstract}

Keywords: Learning Outcomes, Audio Visual Media, Civic Learning

How to Cite: Faizah, (2017), Penggunaan Media Pembelajaran Audio Visual dalam Mata Pelajaran PKn, Anthropos: Jurnal Antropologi Sosial dan Budaya, 3 (1): 55-60 


\section{PENDAHULUAN}

Tujuan PKn adalah untuk membentuk watak warga negara yang baik, yaitu yang tahu, mau dan sadar akan hak dan kewajibannya Untuk mencapai sasaran dan target tersebut, dalam pelaksanaan pembelajaran diperlukan penataan alat, bahan, dan sumber belajar agar dapat dilihat dan mudah digunakan oleh siswa.

Selama ini guru terlalu menganggap remeh pelajaran pendidikan kewarganegaraan (PKn), pembelajaran yang diberikan masih sangat monoton, hanya bercerita dan bersama siswa hanya membaca buku dari satu sumber yang sama dan jarang sekali menggunakan metode dan media yang lebih bervariasi, sehingga motivasi peserta didik untuk mengikuti pembelajaran sangatlah rendah. Seseorang akan berhasil dalam belajar, kalau dirinya sendiri ada keinginan untuk belajar, inilah prinsip dan hukum pertama dalam kegiatan pendidikan dan pengajaran.

Pada observasi yang saya lakukan di kelas 2, ternyata siswa kurang aktif dalam mengikuti pembelajaran, siswa terlihat bosan dan kurang merespon penjelesan saya, siswa juga tidak menunjukan ekspresi gembira dan tidak bersemangat, mungkin hanya coba patuh dan berusaha mengikuti perintah sang guru saja, namun pada akhir pembelajaran terbukti bahwa hasil belajar yang dipeoleh siswa tidak mencapai ketuntasan belajar.

Hal ini terjadi bukan sepenuhnya salah peserta didik yang tidak dapat menjawab dan mengikuti pelajaran dengan baik, namun kita sebagai fasilitator harus selalu mengintropeksi diri dan mencoba melakukan berbagai inovasi yang kreatif dalam penggunaan metode, media ataau model pembelaajaran. Oleh karenanya dalam hal ini saya ingin mencoba menggunakan media Audio visual dalam pembelajaran PKn pada materi akibat tidak memelihara lingkungan.

Merancang media pembelajaran PKn sangat tergantung dari jenis media yang digunakan. Di bawah ini diulas kembali jenis media yang dapat digunakan/dikembangkan dalam pembelajaran PKn, yaitu hal-hal yang bersifat visual, seperti bagan, matriks, gambar, data, dan lain-lain, dan hal-hal yang bersifat materiil, seperti model-model, benda contoh gerak, sikap, dan perilaku, seperti simulasi, bermain peran, role playing, cerita, kasus tentang moral.

Berkaitan dengan hal di atas, maka pembelajaran PKn dapat menggunakan berbagai jenis media yaitu media visual, media audio video atau media berbasis komputer. Namun dari beberapa pilihan media diambil harus mampu memenuhi syarat dan kerakteristik pembelajaran PKn, misalnya mampu mengajak siswa berfikir kritis, dan peka. Hal lain adalah penerapan suatu media dalam proses belajar mengajar PKn yang tentu saja harus disesuaikan dengan pokok bahasan yang ingin kita sampaikan kepada siswa. Sebagai contoh, pokok bahasan akibat tidak memelihara lingkungan. Media audio visual dapat menghadirkan gambaran tentang akibatakibat dari tidak terpeliharanya suatu lingkungan. Dengan demikian para siswa di harapkan dapat memahami pentingnya menjaga dan merawat lingkungan sekitar.

Secara umum tujuan dari penelitian ini adalah untuk mengetahui hasil belajar siswa pada pembelajaran PKn siswa kelas II SD Negeri 101768 Tembung. Sedangkan secara khusus penelitian ini bertujuan meningkatkan aktivitas siswa dan meningkatkan hasil belajar siswa setelah guru menggunakan Media Audio Visual dalam pembelajaran PKn pada materi akibat tidak memelihara lingkungan di kelas II SD Negeri 101768 Tembung

\section{METODE PENELITIAN}

Subjek penelitian ini adalah siswa Kelas II SDN 101768 sebanyak 32 siswa yang terdiri dari 17 siswa laki-laki dan 15 siswa perempuan. Penelitian ini akan dilaksanakan di SD Negeri 101768 Kecamatan Percut Sei Tuan Kabupaten Deli serdang. Objek penelitian ini bertujuan untuk mengetahui peningkatan hasil belajar siswa dalam pembelajaran PKn menggunakan penerapan media pembelajaran Audio Visual. Kegiatan penelitian ini tindakan kelas ini dilaksanakan pada bulan Oktober Tahun 2016. Penelitian yang dilakukan adalah penelitian Tindakan Kelas. Prosedur kerja dalam penelitian ini merupakan siklus kegiatan yang 
terdiri dari dua siklus. Masing-masing siklus meliputi perencanaan, tindakan, pengamatan atau observasi dan refleksi. Teknik penngumpulan data dalam penelitian ini adalah observasi, angket, tes.

\section{HASIL DAN PEMBAHASAN}

Untuk mengetahui kondisi awal hasil belajar siswa sebelum dilakukan penelitian maka pengambilan data hasil belajar siswa dengan pre test terlebih dahulu. Kegiatan ini diikuti seluruh siswa kelas II SD Negeri 101768 yang berjumlah 30 siswa. Data yang diambil berupa hasil pekerjaan siswa pada mata pelajaran PKn dengan materi akibat tidak memelihara lingkungan. Dan diperoleh hasil nilai rata-rata sebelum tindakan hanya 62,33. Masih banyak siswa yang belum mencapai nilai kriteria ketuntasan mimimal, yaitu sebanyak 17 siswa. Sedangkan yang sudah tuntas mencapai nilai KKM ada 13 siswa.

Di akhir siklus I, guru meminta siswa mengerjakan soal evaluasi untuk mengukur kemampuan siswa terhadap materi dengan menggunakan media Audio Visual . Kemudian dari data tersebut masih ada siswa yang tuntas dan belum tuntas pada siklus I dapat dilihat pada tabel berikut.

Tabel 1 Perbandingan Siswa yang Tuntas atau belum Tuntas dari Hasil Pra Tindakan dan Tes Evaluasi Akhir Siklus I

\begin{tabular}{|l|l|l|l|}
\hline NO & Waktu & $\begin{array}{l}\text { Siswa } \\
\text { tuntas }\end{array}$ & $\begin{array}{l}\text { Siswa belum } \\
\text { tuntas }\end{array}$ \\
\hline 1 & $\begin{array}{l}\text { Pra } \\
\text { Tindakan }\end{array}$ & 13 siswa & 17 siswa \\
\hline 2 & Siklus I & 22 siswa & 8 siswa \\
\hline
\end{tabular}

Berdasarkan tabel perbandingan hasil pra tindakan dan tes evaluasi akhir tersebut dapat dinyatakan bahwa 22 siswa sudah mencapai nilai KKM sedangkan 8 siswa belum mencapai nilai KKM pada siklus I. Nilai rata-rata yang diperoleh siswa sudah mencapai kriteria yaitu 83,00, tetapi persentase ketuntasan belajar siswa masih belum sesuai dengan yang diharapan karena hanya mencapai 73,33\%.

Tabel 2 Perbandingan nilai rata-rata siswa pada pra tindakan dan siklus I

\begin{tabular}{|l|l|l|l|}
\hline No. & $\begin{array}{l}\text { Point } \\
\text { Perbandingan }\end{array}$ & $\begin{array}{l}\text { Pra } \\
\text { Tindakan }\end{array}$ & $\begin{array}{l}\text { Evaluasi } \\
\text { Siklus I }\end{array}$ \\
\hline 1. & Nilai Rata-rata & 62,33 & 83,00 \\
\hline 2. & $\begin{array}{l}\text { Persentase } \\
\text { Ketuntasan } \\
\text { Belajar Siswa }\end{array}$ & $43,33 \%$ & $73,33 \%$ \\
\hline
\end{tabular}

Berdasarkan tabel nilai rata-rata siswa dapat dinyatakan bahwa nilai rata-rata dari pra tindakan adalah 62,33 sedangkan nilai rata-rata evaluasi siklus I adalah 83,00.

Dari hasil tersebut dapat dilihat pada diagram perbandingan nilai rata-rata siswa pada Pra Tindakan dan nilai rata-rata siswa siklus I disajikan di bawah ini.

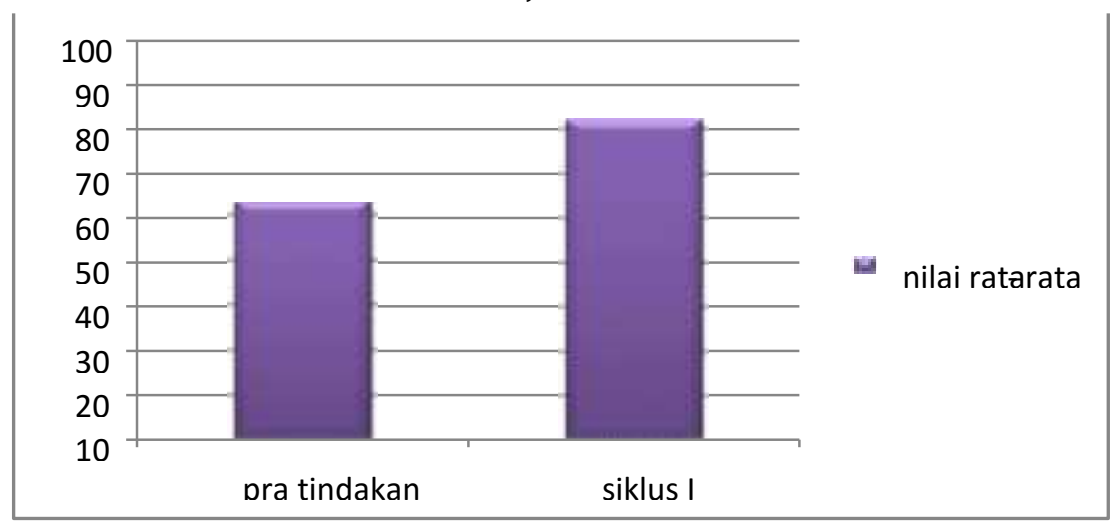

Gbr. 7. Diagram Batang Nilai Rata-Rata Pra Tindakan Dan Nilai Rata-Rata Siklus I 
Faizah, Penggunaan Media Pembelajaran Audio Visual dalam Mata Pelajaran PKn

Pada tahap siklus ke dua, siswa juga terlihat antusias. Peningkatan hasil nilai rata-rata dari pra tindakan hingga akhir siklus II dapat dilihat pada tabel berikut: Tabel 3 Perbandingan Nilai Rata-Rata Pra Tindakan, Evaluasi Siklus I dan Evaluasi Siklus II

\begin{tabular}{|l|l|l|l|l|}
\hline No. & Point Perbandingan & Pra Tindakan & Evaluasi Siklus I & Evaluasi Siklus II \\
\hline 1. & Nilai Rata-rata & 62,33 & 83,00 & 92,23 \\
\hline 2. & Persentase Ketuntasan Belajar Siswa & $43,33 \%$ & $73,33 \%$ & $86,67 \%$ \\
\hline
\end{tabular}

Berdasarkan tabel di atas dapat diketahui bahwa nilai rata-rata siswa meningkat pada setiap siklus. Pada siklus I terjadi peningkatan nilai rata-rata sebesar 20,67 point dari kondisi awal, sedangkan pada siklus II terjadi peningkatan sebesar 9,23 point dari siklus I.
Peningkatan dari kondisi awal ke siklus I dan dari kondisi siklus I ke kondisi siklus II terlihat baik dengan terjadi peningkatan. Selain itu siswa juga merasa senang dalam mengikuti pembelajaran dengan menggunkan media

Audio Visual .

Hasil perbandingan nilai rata-rata pra tindakan, evaluasi siklus I dan evaluasi siklus II dapat dilihat pada diagram berikut:

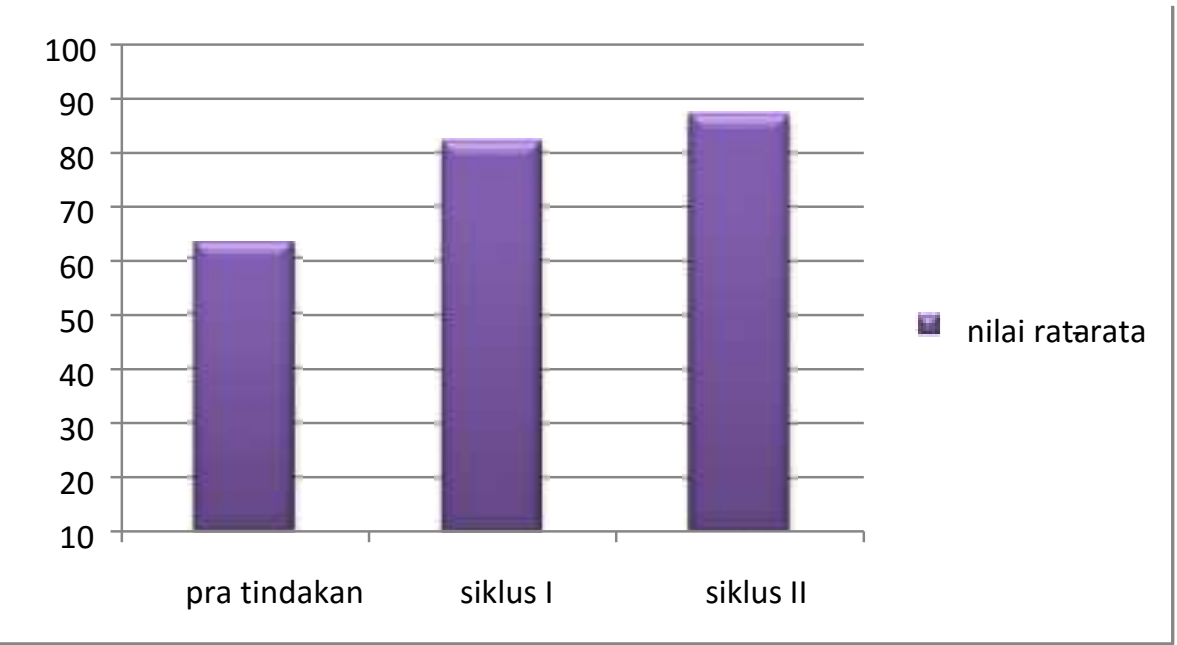

Gbr. 3. Diagram Batang Perbandingan Nilai Rata-Rata Pra Tindakan, Evaluasi Siklus I dan Evaluasi Siklus II

Dari hasil penelitian dapat dilihat pada diagram batang di atas menunjukkan bahwa data hasil tes nilai rata-rata pra tindakan, siklus I dan siklus II juga mengalami peningkatan.

Untuk mengetahui kondisi awal hasil belajar siswa sebelum dilakukan penelitian maka pengambilan data hasil belajar siswa dengan pre test terlebih dahulu. Kegiatan ini diikuti seluruh siswa kelas II SD Negeri 101768 yang berjumlah 30 siswa. Data yang diambil berupa hasil pekerjaan siswa pada mata pelajaran PKn dengan materi akibat tidak memelihara lingkungan. Dan diperoleh hasil nilai rata-rata sebelum tindakan hanya 62,33. Masih banyak siswa yang belum mencapai nilai kriteria ketuntasan mimimal, yaitu sebanyak 17 siswa. Sedangkan yang sudah tuntas mencapai nilai KKM ada 13 siswa.

Di akhir siklus I, guru meminta siswa mengerjakan soal evaluasi untuk mengukur kemampuan siswa terhadap materi dengan menggunakan media Audio Visual. Kemudian dari data tersebut masih ada siswa yang tuntas dan belum tuntas pada siklus I.

Hasil pra tindakan dan tes evaluasi akhir tersebut dapat dinyatakan bahwa 22 siswa 
sudah mencapai nilai KKM sedangkan 8 siswa belum mencapai nilai KKM pada siklus I. Nilai rata-rata yang diperoleh siswa sudah mencapai kriteria yaitu 83,00, tetapi persentase ketuntasan belajar siswa masih belum sesuai dengan yang diharapan karena hanya mencapai $73,33 \%$.

Nilai rata-rata siswa dapat dinyatakan bahwa nilai rata-rata dari pra tindakan adalah 62,33 sedangkan nilai rata-rata evaluasi siklus I adalah 83,00.

Nilai rata-rata siswa meningkat pada setiap siklus. Pada siklus I terjadi peningkatan nilai rata-rata sebesar 20,67 point dari kondisi awal, sedangkan pada siklus II terjadi peningkatan sebesar 9,23 point dari siklus I. Peningkatan dari kondisi awal ke siklus I dan dari kondisi siklus I ke kondisi siklus II terlihat baik dengan terjadi peningkatan. Selain itu siswa juga merasa senang dalam mengikuti pembelajaran dengan menggunkan media Audio Visual .

Dari hasil penelitian dapat dilihat pada diagram batang di atas menunjukkan bahwa data hasil tes nilai rata-rata pra tindakan, siklus I dan siklus II juga mengalami peningkatan.

Hasil penelitian menunjukkan bahwa hasil belajar siswa kelas II SD N 101768 meningkat setelah menggunakan media Audio Visual.

Setiap tindakan materi mengalami peningkatan. Secara keseluruhan dapat dilihat pada aktivitas siswa dari siklus pertama dan siklus kedua telah mengalami peningkatan. Hal tersebut dapat dilihat pada hasil siklus pertama yang mencapai nilai rata-rata 83,00 sedangkan pada siklus kedua nilai rata-rata juga mengalami peningkatan menjadi 92,23. Meskipun peningkatannya hanya 9,23\% tetap saja mengalami peningkatan.

Berdasarkan pembahasan hasil penelitian tersebut dapat dikatakan pembelajaran yang telah dilakukan dengan menggunakan media Audio Visual memberikan kesimpulan bahwa pembelajaran dengan menggunakan media Audio Visual pada materi akibat tidak merawat lingkungan dapat meningkatkan hasil belajar siswa kelas II SD N 101768 Percut Sei Tuan .

\section{KESIMPULAN}

Berdasarkan hasil penelitian dan pembahasan, dapat disimpulkan bahwa dengan menggunakan media Audio Visual dalam pembelajaran PKn dapat meningkatkan hasil belajar pada siswa kelas II SD Negeri 101768 ini terlaksana melalui dua siklus yaitu siklus I dan siklus II. Masing-masing siklus terdiri dari dua kali pertemuan. Sebelum dilakukannya tindakan, nilai rata-rata siswa hanya mencapai 62,33 dengan persentase ketuntasan siswa 43,33\% atau sebanyak 17 siswa yang belum tuntas dari 30 siswa. Pada siklus I diperoleh nilai rata-rata siswa mencapai 83,00 dengan persentase ketuntasan siswa $73,33 \%$ atau sebanyak 8 siswa yang belum tuntas dari 30 siswa. Nilai rata-rata mengalami peningkatan sebesar 20,67 point sedangkan ketuntasan siswa mengalami peningkatan sebesar 30\%. Pada siklus II diperoleh nilai rata-rata siswa sebesar 92,23 dengan persentase ketuntasan siswa 86,67\% atau sebanyak 4 siswa yang belum tuntas dari 30 siswa. Pada siklus II ini nilai rata-rata mengalami peningkatan sebesar 9,23 point sedangkan persentasenya mengalami peningkatan sebesar 13,34\%. Hal tesebut menunjukkan bahwa pembelajaran dengan menggunakan media Audio Visual sudah terlaksana dengan baik sesuai dengan yang diharapan dan mengalami peningkatan.

\section{DAFTAR PUSTAKA}

Ahmad Djazuli, dik (1997). Penyelenggaraan Pendidikan di Sekolah Dasar. Jakarta: Depdikbud.

Akhmad Sudrajat. (2008). Konsep media Pembelajaran

http://akhmadsudrajat.wordpress.com/2008 /01/12/konsep-media-pembelajaran/ diakses pada tanggal 7 Agustus 2016 waktu 21.20 WIB.

Azhar, Arsyad. 2011. Media Pembelajaran. Jakarta: Raja Grofindo Persada. Coletta, Vincent P., Jeffry A. Philips., dan Jeffrey J. Steinert. 2007. The

American Physical Society. Interpreting force concept inventory scores:Normalized gain and SAT scores, 3 (1) : 1-5. 
Faizah, Penggunaan Media Pembelajaran Audio Visual dalam Mata Pelajaran PKn

Mulyasa. 2007. Kurikulum Tingkat Satuan Sudjana. 2002. Metode Statistika. Bandung: Tarsito. Pendidikan (Suatu Panduan Praktis). Sugiyanto. 2001. Perkembangan dan belajar motorik. Bandung: PT. Remaja Rosda Karya.

Putu Sutrisna. (2011) Penerapan Media Audio Visual http://putusutrisna.blogspot.com/2011/04/ penerapan-media-audio-visual-untuk.html diakses pada tanggal 7 Agustus 2016 waktu 22.10 WIB.

Slameto. (2010). Belajar dan Faktor-faktor yang mempenagruhi. Jakarta: Rineka Cipta Jakarta: Departemen Pendidikan Nasional. Suharsimi Arikunto, dkk. 2009. Penelitian Tindakan Kelas. Jakarta: Bumi Aksara.

Sukintaka. 1992. Teori Bermain. Jakarta: Depdikbud Susilo. 2011. Panduan Penelitian Tindakan Kelas. Sleman Yogyakarta: Penerbit Pararaton 